\title{
Teacher Training Program of the East Kutai Regency Office of Education, East Borneo
}

\author{
Khusnul Wardan ${ }^{1}$, Susilo Susilo², Saraka Saraka ${ }^{2}$, Hasbi Sjamsir ${ }^{2}$, \\ ${ }^{1}$ Educational Management Department, Mulawarman University, East Borneo, Indonesia \\ ${ }^{2}$ Educational Management Department, College Education, Mulawarman University, East Borneo, Indonesia

\section{Email address:} \\ wardankhusnul@yahoo.co.id (K. Wardan), olisusunmul@gmail.com (S. Susilo), saraka.ali30@gmail.com(S. Saraka), \\ hasbisjamsir@fkip.unmul.ac.id (H. Sjamsir) \\ ${ }^{*}$ Corresponding author
}

\section{To cite this article:}

Khusnul Wardan, Susilo Susilo, Saraka Saraka, Hasbi Sjamsir. Teacher Training Program of the East Kutai Regency Office of Education, East Borneo. International Journal of Secondary Education. Vol. 8, No. 2, 2020, pp. 47-52. doi: 10.11648/j.ijsedu.20200802.14

Received: August 8, 2019; Accepted: February 28, 2020; Published: June 3, 2020

\begin{abstract}
This study aimed to describe the Quality Development Program of the Education Office of East Kutai District Teachers. In this phenomenological qualitative research, researchers want to photograph, analyze and construct teachers and the environment as both subject and research respondents. Methods of collecting data by interview. Data analysis techniques used qualitative data analysis techniques of Miles and Huberman interactive models, namely data reduction, data display and reduction / conclusion. The teacher quality development program by the East Kutai District Education Office is carried out by implementing several programs namely (1) education equalization programs, (2) education and training programs, (3) supervision programs by supervisors and principals, (4) Employment Group empowerment programs Teachers and Deliberation of Subject Teachers, (5) comparative studies to schools in Java, (6) certification programs and (7) teacher performance assessment programs. All of these programs have been running well and can improve the quality of teachers in the East Kutai Education Office.
\end{abstract}

Keywords: Coaching, Quality, Training

\section{Introduction}

Teachers are equal to the noblemen or the gentry according to Geertz's typology of Javanese society. The word 'teacher' in Javanese society stands for digugu omongane lan ditiru kelakoane (to be obeyed and imitated). This term contains the meaning that "A teacher is someone whose words are always noticed and a role model who acts as a guide". Becoming a teacher used to be a dream for most children since this profession held a high social status in the society [1]. At that time, a teacher was seen to have a position similar to a public official with a great charisma either for himself or for his family. People also notice every single detail of his behavior when interacting with his surroundings. This image is shaped because a teacher should carefully preserve his integrity as well as credibility. A teacher is not a person whose job is only to teach in front of the class, he/she also educates, guides, leads and shapes students' good moral characters.
Nowadays, the teaching profession still becomes the most discussed topic, or is often questioned by education or non-education experts. Even in the last decade, the printed mass media provides the news about teacher published daily or weekly. Ironically, many of these news stories tend to discomfit the teacher position whether they are related to general or personal things, meanwhile, the teacher is barely able to defend himself. The community and students' parents sometimes insult or accuse teachers of being incompetent, unqualified and others when their children are not able to solve their own problems or have no ability as what they are expected.

As a role model, a teacher exists because his position or role is even irreplaceable with a sophisticated machine. His role involves fostering aspects of human nature which are uniquely different from each other. The problem is related to the community recognition for teacher profession which is considered lower than other professions such as judge and doctor. If the standards of professional recognition are the 
expertise and the level of education, there are also teachers whose level of education is equal or even higher than the other professions. We can admit that teacher is a most easily tainted profession. It means that there are still people who force themselves to become teachers although they are not prepared for such profession. This occurs because of social perspectives on those who are knowledgeable have an opportunity to be a teacher.

At this moment, teacher's value, integrity and credibility are rather outdated. Teacher profession is considered as less prestigious job which is mainly seen from its income and future plan. This is different from the other professions which tend to offer instant wealth in the materialistic era. Young people with high intelligence are very rare to choose teacher as their future profession even though their parents are also teachers [2].

One of many factors that lower the level of community recognition for teacher profession mainly originates from the teacher himself. The factor is the low level of teacher's professional competence. The mastery of material and teaching method is below standard. From this fact, teacher competence needs to be improved. Some Indonesian teachers are unqualified to teach. The percentages of teachers who are qualified to teach are as follows: teachers who are qualified to teach in elementary school level are $21,07 \%$ (state) and $28,94 \%$ (private), teachers who are qualified to teach in secondary school level are 54,12\% (state) and 60,99\% (private), teachers who are qualified to teach in high school level are 65,29\% (state) and 64,73\% (private), and teachers who are qualified to teach in vocational high school are 55,49\% (state) and 58,26\% (private). ${ }^{[3]}$ The other factor that also causes low recognition level within the community towards teacher profession is teacher's self-weakness.

The fact is some teachers are still unaware of their duties and responsibilities and sometimes ignore their obligations. For example, they often come late to school and consequently this curtails their two or three teaching hours, and they pay less attention to the arrangement of teaching program such as annual program, semester program, syllabus, lesson plan, and remedial. It still can be found that teachers teach their students without any clear objectives and they only aim to complete the explanation of the teaching material. Teachers will conduct remedial program if there is an instruction from the school headmaster. If no instruction given by the headmaster, the teachers do not provide counseling for their students. This illustrates the low level of teacher performance. As stated by Sjamsir and Honest, (2017) in, Sapril, Haruna, Saraka and Sjamsir, (2018), that teachers' performance is influenced by the school management roles such as leadership role, managerial role, curriculum and instructional role. Moreover, Zulkifli (2017) stated that management needs include hard and soft applications, both conventional and advanced, such as artificial intelligence such as fuzzy logic, neural network and genetic algorithms that can improve the productivity of a managed supply chain system.

There are several research results on teacher quality development programs as the results of the research from Douglas N. Harris dan Tim R. Sass (2008). Our results suggest that only two of the forms of teacher training we study influence productivity. First, content-focused teacher professional development is positively associated with productivity in middle and high school math. Second, more experienced teachers appear more effective in teaching elementary math and reading and middle school math. There is no evidence that either pre-service (undergraduate) training or the scholastic aptitude of teachers influences their ability to increase student achievement [4].

Several efforts made by the school to improve teacher professionalism are: (1) Classroom Action Research training; (2) lesson study activity; (3) on the job training; (4) in service training; (5) internship program at DUDI; (6) Quality assurance program after teacher certification; (7) MGMP-based training; and (8) teacher internship program [5]. In general, teacher training program is conducted based on four preliminary stages: (1) preparing resources; (2) preparing teacher data; (3) making strategies; and (4) identifying training-related aspects. For the training purpose, the headmaster forms a team to identify training-related aspects [6].

\section{Research Questions}

Several questions were addressed in this research:

1. How is the form of educational equalization program conducted at Education Department of East Kutai Regency?

2. What are the training programs which have been done by the East Kutai Regency Office of Education?

3. How is the educational supervision implemented by the Office of Education, the supervisor and the school headmaster?

4. How is the empowerment program of KKG and MGMP implemented by the East Kutai Regency Office of Education?

5. Is the implementation of comparative study able to improve the teacher quality in East Kutai?

6. How is the implementation of teacher certification at the East Kutai Regency Office of Education?

7. How is the Teacher Performance Assessment conducted at the East Kutai Regency Office of Education?

\section{Research Methodology}

The objectives of this study were: (1) To describe how the education equalization program was carried out by the East Kutai District Education Office, (2) to describe what training programs had been carried out by the East Kutai District Education Office, (3) to describe how to implement education supervision by the Education Office, supervisors and Principals, (4) To describe how the KKG and MGMP District Education Office Empowerment Program forms (5) To describe whether comparative studies carried out can improve the quality of teachers in East Kutai, (6) To describe 
how the implementation of teacher certification at the East Kutai District Education Office, (7) To describe how the implementation of teacher performance assessment at the East Kutai District Education Office.

Data and data sources in this study were the head of the East Kutai District Education Office, the Head of the Quality Improvement Division for Educators and Education Personnel (PMPTK) of the Kutai Timur District Education Office, the Head of Section (Kasi) of the Basic Education Office of the East Kutai District, the Principal in East Kutai and Teachers in the East Kutai District Education Office. The research method used to raise information is interview. The approach used in this research is phenomenological qualitative, meaning that the researcher tries to photograph, analyze and construct the situation of the teacher and the environment as a subject as well as a research respondent. Data collection method by interview. Data analysis techniques use qualitative data analysis techniques of the Miles and Huberman interactive models, namely data reduction, display data and withdrawal / verification or conclusions.

\section{Theoretical Framework}

Etymologically, a teacher is mostly known as an educator. In Arabic language, there are some words that have similar meaning with an educator such as mudarris, mu'allim and mu'addib. Although having similar meaning, each of them has different characteristic. In addition, the term ustadz or syaikh also represents another term for an educator. These appellations were based on the recommendation of International Education Conference held in Mecca in 1977 which state that education involves three definitions namely tarbiyah, ta'lim and ta'dib. To conclude, the definition of teacher or educator involves murabbi, mu'allim and mu'addib.

The definition of murabbi represents that a teacher possesses rabbani characteristics meaning that he/she is a wise, responsible person, loves his/her students and has knowledge of rabb. Next, mu'allim describes a teacher as the one not only mastering theoretical knowledge, but also having high commitment towards the development of sciences. The last is ta'dib concept which explains about the integrity of knowledge and deed. Terminologically, a teacher is often defined as the one who is responsible for the development of students' cognitive, affective and psychomotoric potential. A teacher is an adult who is responsible for helping students become more mature physically and spiritually, fulfilling their individual tasks as a servant ('abd) and a God's caliph, a social creature and an independent person.

It is stated in Law of the Republic Indonesia Number 14 Year 2005 article 1 section (1) on teacher and lecturer that: "A teacher is a professional educator with the main duties to educate, teach, guide, direct, train, assess and evaluate students of early childhood formal education, elementary education and secondary education". A teacher is an educational profession. Through Regulation of the Minister of National Education Number 16 Year 2007, it is stated that a teacher should have some academic qualifications. One of the academic qualifications is completing education or formal teacher training according to the levels of PAUD/TK/RA, SD/MI, SMP/MTs and SMA/MA.

In accordance with Law of the Republic Indonesia Number 14 Year 2005, an educator should have fundamental principles. Teacher and lecturer are special professions with the following principles: (1) showing talent, interest and idealism; (2) having commitment to improve education quality, faith, piety, and honourable attitude; (3) having both academic qualification and background relevant to educational field; (4) having competence relevant to educational field; (5) having responsibility to accomplish professional tasks; (6) receiving salary based on the work performance; (7) having opportunity to develop sustained professionalism.

The minimal standards of the professional teacher according to Suyanto are: (1) having good intelligence; (2) having the ability to comprehend the vision and mission of national education; (3) having expertise in transferring knowledge to students effectively; (4) understanding the concept of child' psychological development; (5) having the ability to organize learning process; (6) having creativity and art of teaching.

According to Queensland Department of Education, there are 12 professional standards owned by teachers: (1) Structure flexible and innovative learning experiences for individuals and groups, (2) Contribute to language, literacy, and numeracy development, (3) Construct intellectually challenging learning experiences, (4) Construct relevant learning experiences that connect with the world beyond school, (5) Construct inclusive and participatory learning experiences, (6) Integrate information and communication technologies to enhance student learning, (7) Assess and report on student learning, (8) Support the social development and participation of young people, (9) Create safe and supportive learning environments, (10) Build relationship with wider community, (11) Contribute to professional teams, (12) Commit to professional practice.

In educational field, teachers have strategic roles which are also known as the 'spearhead' of the success of education. Therefore, to improve the quality of education, the first thing that is needed to improve is teacher quality. One of many ways to improve teacher quality is developing teacher professionalism in terms of attitude and competence. There are several aspects that are required to have to be a professional teacher such as: (1) academic qualification; (2) competence; (3) teacher certification; (4) physical health; (5) ability to achieve the objectives of national education. It would not be easy to have a role as a teacher and therefore there are not many people who have passion to accomplish the tasks as teachers. According to Qomari Anwar, there are some qualifications required to be a teacher such as: (1) pious follower of Allah SWT; (2) knowledgeable; (3) physically healthy; (4) good attitude. 
Teachers experience a vast range of activities and interactions that may increase their knowledge and skills and improve their teaching practice, as well as contribute to their personal, social, and emotional growth as teachers. These experiences can range from formal, structured topic-specific seminars given on in-service days, to everyday, informal "hallway" discussions with other teachers about instruction techniques, embedded in teachers' everyday work lives.

\section{Research Finding}

\subsection{The Education Equalization Program Held by the Office of Education, East Kutai Regency}

From the findings presentation, it could be concluded as follows: First, the education equalization program for S1 level had run well with the funding scheme of study leave for teachers who would like to continue their education to the S1 (undergraduate) level. The Office of Education had to do a comprehensive evaluation concerning the system of equalization program that had been implemented so far from the student recruitment system, learning system to the quality of lecturers. Second, the qualification program for S2 and S3 (postgraduate) levels had not run well yet. The S2 and S3 qualification programs had to be re-implemented by the Office of Education of East Kutai Regency since there were still a lot of teachers teaching at the Junior High School and Senior/ Vocational High School levels with an undergraduate (S1) qualification. Third, in order to materialize the educational qualification programs at S1, S2 and S3 levels, the Office of Education of East Kutai Regency should do a brilliant breakthrough concerning the funding scheme for the qualification program itself. Thus, cooperation should be established with various parties, which included the private sectors in East Kutai.

\subsection{The Training Program Conducted by the East Kutai Office of Education}

Related to the training program, it could be summed up as follows: First, there should be an equal opportunity given to the teachers from the rural, suburban and urban areas to join the training conducted so far. This equal opportunity should be given considering the justice principle and the opportunity to attend any training programs for any teachers in East Kutai. Second, the follow-up for the teachers after the training should be done so that the teachers who had attended the program would feel that they were given enough attention by the Office of Education. Based on the field observation result, most teachers who attended the training program felt lazy to practice what they had learned from the training neither were they motivated to share what they had obtained from the training to other teachers. Third, the empowerment of teachers who qualified as national instructors should be done by the East Kutai Office of Education as a reward for them. Fourth, the Office of Education should conduct a comprehensive evaluation towards all training programs that they had implemented so far. This evaluation would be related to the planning of the training program, the organization of the training program and the implementation of the training program itself.

\subsection{The Supervision Program Done by the Office of Education, Supervisors and School Principals in East Kutai}

Concerning the supervision program, it could be concluded as follows: First, the supervision implemented by the supervisors had not run as expected. The supervisions at schools were not maximally done yet with various reasons. Second, the supervisions by the school principals had been implemented well and maximally. The School Principals who had a double role as supervisors had implemented their functions well. The School Principals as supervisors were expected not only to do an administrative supervision on the teachers but also to do an academic supervision in which observing directly how the teachers teach in the class. Third, in order to perform their duties as both supervisors and School Principals, they need to improve their competences especially in supervising.

Fourth, the ratio of the number of supervisors and supervised teachers need to be improved. The fact from the field had indicated that there were an unequal number of supervisors and the teachers they supervised. There were supervisors who supervised teachers beyond their capacities. Fifth, the East Kutai Regency Office of Education had to conduct a training program for supervisors, supervisor candidates and assessors from the senior teachers. This training program would be necessary to do in order to expand the knowledge of the supervisors and supervisor candidates in terms of supervision implementation as well as licensing for the supervisor candidates and assessors from the senior teachers.

\subsection{Program and Implementation of Teacher Work Group and Subject Teacher Forum at the East Kutai Regency Office of Education}

The conclusion of the implementation of the Teacher Working Group and Subject Teacher Consultation at the East Kutai District Education Office is as follows: First, the implementation of the Teacher Work Group and Subject Teacher Consultation at the East Kutai District Education Office has been going well but there needs to be improvements in its implementation. Second, in the implementation of Teacher Working Groups and Subject Teacher Consultations, careful planning is needed so that the desired results can be achieved. This planning needs to be done to facilitate managers in carrying out all activities that will be carried out. Planning includes the creation of Standard Operating Procedures for Teacher Working Groups and Subject Teacher Meetings, implementation schedules, organizing the implementation of Teacher Working Groups and Subject Teacher Meetings, the materials will be discussed in the activities of the Teacher Working Group and Subject Teacher Consultation and evaluation. 
Third, the role of the Education Office in the development of Teacher Working Groups and Subject Teacher Consultations is still not optimal. Data in the field shows that the Education Office rarely monitors or supervises the implementation of the Teacher Working Group activities and Subject Teacher Consultations, each time invited at the Teacher Working Group meetings and Subject Teacher Meetings the Education Agency is rarely present at the meeting. Fourth, supporting facilities for Teacher Group Work activities and Subject Teacher Consultations are still far from complete. During this time the implementation of Teacher Working Groups and Subject Teacher Consultations still used the facilities of each school which was used as a meeting place. There needs to be a new breakthrough by the East Kutai District Education Office to equip the facilities especially the building of the Teacher Working Group secretariat and the Fifth Subject Teacher Consultation, the role of the school is also expected to be maximal in facilitating each teacher who will take part in the Teacher Working Group activities and Subject Teacher Meetings. The facility can be in the form of transportation and accommodation money that is sufficient in accordance with the ability of each school's budget. And Sixth, the participation of teachers in Teacher Working Group activities and Subject Teacher Meetings is still lacking. There are still many teachers who do not want to attend when invited to participate in the activity.

\subsection{The Comparative Study Trip Conducted by the East Kutai Regency Office of Education}

From the findings presentation, it could be concluded as follows: First, the comparative study trip conducted by the Office of Education has been done and implemented well. The comparative study trip was done by some schools in Sangatta Municipality, including elementary schools, Junior High Schools, Senior High Schools and Vocational Schools. Second, equal opportunities for other schools to do a comparative study trip were necessary. This was because the schools located in the suburban and rural areas would also like to do a comparative study trip. Third, a well-made plan would be necessary for comparative study trip implementation. This planning should be done so that the comparative study trip conducted would result in something new which could be useful for the improvement of teacher quality in East Kutai. Moreover, the image of comparative study trip as a recreation only could be minimalized. Four, the Office of Education must do a routine evaluation to see whether the comparative study trip done so far had been implemented as expected or not. The Office of Education should also consider the impact of the comparative study trip whether it could improve the teacher quality or not, or whether it could improve the quality of teaching and learning process or otherwise, it did not give a significant effect on the improvement of teacher quality in East Kutai.

\subsection{The Teacher Certification Program of the East Kutai Regency Office of Education}

Based on the results of field observation and interview concerning the certification program held by the East Kutai Regency Office of Education, it could be concluded as follows: First, the teacher certification program in East Kutai had been implemented in a different way from the previous years. This certification program was still done by the East Kutai Regency Office of Education considering that there were still a lot of teachers who had not been certified yet. Second, from the field observation, it was still found that the certification incentives were not used as expected. There were still a lot of teachers who spent their certification incentives to add to their assets such as in the forms of cars, motorcycles, houses and other immovable assets. Third, the post-certification development program from the East Kutai Regency Office of Education was still lacking. Based on the results of the field observation and interview, it was found that the Office of Education had not done any post-certification development program for the teachers. The post-certification development program would be necessary to do because not all teachers who had been certified could implement what they had learned during the certification training.

\subsection{The Teacher Performance Assessment Program of the East Kutai Regency Office of Education}

From the interview results described above, the Teacher Performance Assessment conducted by the East Kutai Regency Office of Education could be summed up as follows: First, the implementation of the Teacher Performance Evaluation by the School Principals and Assessors was running well, which could be reflected from the results of the field observation and interview. All the respondents answered that they had been assessed by the School Principals and the Assessors from Senior Teachers. In principle, the teachers were happy with the assessment because it was a part of the teacher quality development program.

Second, based on the data from the field, there were a lot of teachers who did not know the components being assessed in the Teacher Performance Assessment by the School Principals. In order to provide a comprehensive understanding to the teachers, the School Principals should socialize the implementation of the Teacher Performance Assessment and the components being assessed. This socialization program should be done so that the teachers would have similar perception on the implementation of the Teacher Performance Assessment done by the School Principals. Third, the School Principals should do an evaluation of the Teacher Performance Assessment that had been done so far. This evaluation aimed at knowing the extent to which the implementation of TPA had been successful as well as the contribution of TPA towards the teacher quality improvement in East Kutai. The aspects to be evaluated included the planning of TPA, the organization of TPA and the implementation of TPA.

\section{Conclusion}

The teacher quality development program done by the East Kutai Regency Office of Education included a number of programs such as: (1) the education equalization program, (2) 
training programs, (3) supervision program by supervisors and School Principals, (4) Employment Group empowerment programs Teachers and Deliberation of Subject Teachers (5) comparative study trip studi banding ke sekolah yang ada di pulau Jawa, (6) certification program and (7) teacher performance assessment program. All those programs had been implemented well and could improve the teacher quality at the East Kutai Regency Office of Education.

\section{Acknowledgements}

Let the authors express their sincere gratitude and appreciation and also thanks to all those who provide the following suggestions and direction.

1. Masjaya as a Rector of Mulawarman University, Samarinda, Indonesia.

2. Hasbi Sjamsir, as Chair of the Educational Management Doctoral Study Program and as a corresponding author at Samarinda Mulawarman University.

3. Susilo, Susilo and Saraka, Saraka as the supervisors of the authors

4. Last but not least, thank you to all the authors of the articles that I have quoted in our article

For this reason, the authors expect suggestions and criticisms that are constructive from all parties to improve writing in the future.

\section{References}

[1] Clifford Greetz, Abangan, Santri Priyayi in Javanese Society, Translating Aswab Mahasin, Jakarta: Pustaka Jaya, 1989.

[2] Nanat Fatah Natsir, Improving Teacher Quality in the Perspective of Islamic Education, Journal of Educationist No. I Vol. I January 2007.

[3] Arif Rahman, the Pattern of Promoting Professionalism Improvement for Teachers of Medan City Vocational Schools, Tabularasa PPS UNIMED Journal vol. 10 No. 1, April 2013.

[4] Muhaimin and Abdul Mujib, Thought of Islamic Education, Philosophical Studies and the Basic Operational Framework, Bandung: Trigenda Karya, 1993.
[5] Ramayulis, Islamic Education, Jakarta: Kalam Mulia, 2004.

[6] Ahmad Tafsir, Philosophy of Islamic Education, Physical Integration, Spirituality and Heart, Humanizing Humans, Bandung: Youth Rosdakarya, 2006.

[7] Republic of Indonesia Law Number 14 of 2005 concerning Teachers and Lecturers.

[8] Suyanto, How to become a Prospective Teacher and Professional Teacher, Yogyakarta: Multi Presindo, 2012.

[9] The State of Queensland (Department of Education), Professional standards for Teacher Guedelines for Professional Practice, Brisbane: Gueensland Departmant of Educatioan, 2005.

[10] National Education Lecturer Team, Professional Teachers, Bandung: Alfabeta, 2016).

[11] Qomari Anwar, Stress Management According to Islamic Views, Jakarta: Mawardi Prima, 2003.

[12] Douglas N. Harris dan Tim R. Sass, Teacher Training, Teacher Quality And Student Achievement, (Jurnal Internasional, Center of Analysis of Longitudinal Data in Education Research (Urban Institute), March 12, 2008)

[13] Laura M. Desimone, Improving Impact Studies of Teachers' Professional Development: Toward Better Conceptualizations and Measures, (Educational Researcher, Vol. 38, No. 3, pp. 181-199, DOI: 10.3102/0013189X08331140, (C) 2009 AERA. http://er.aera.net)

[14] Sjamsir, Hasbi. BH. Gunarto. 2017. The implementation of 7 Ps (Marketing Mix) Strategies in Building Network of Partnership towards an Independent the Early Childhood Institution. Available at: http://journal2.um.ac.id/index.php/jmsp/article/view/1871 https://doi.org/10.17977/um025v1i22017p165

[15] Sapril, Haruna, Saraka and Sjamsir, 2018. Secondary School Teachers' Performances at Sandaran Sub-District of East Kutai District East Kalimantan Indonesia. The Journal of Social Sciences Research, Academic Research Publishing Group, vol. 4 (5), pages 80-83, 05-2018. Available at: https://arpgweb.com/journal/7/archive/05-2018/5/4

[16] Zulkifli, 2017. Assessment Supply Chain Performance and Risk of Agricultural Commodities in South of Sulawesi. Available at: https://ijsrm.in/index.php/ijsrm/article/view/747. 